\section{Sterkt om kreft og kjærlighet}

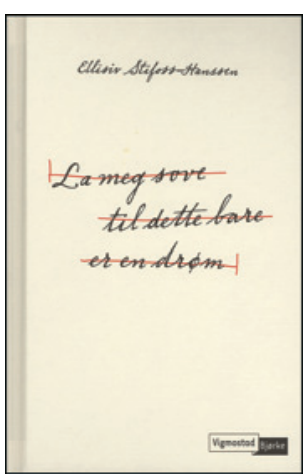

Ellisiv Stifoss-Hanssen

La meg sove til dette bare er en drøm

192 s. Bergen: Vigmostad og Bjørke, 2014.

Pris NOK 329

ISBN 978-82-419-1020-3

I debutromanen La meg sove til dette bare er en drøm skildrer forfatteren Ellisiv Stifoss-Hanssen en 26 år gammel kvinne, Mia, som rammes av livmorhalskreft. Vi følger Mia gjennom hennes møte med diagnosen, helsevesenet og den krevende behandlingen. Like etter at hun får diagnosen, blir det slutt mellom Mia og kjæresten Anne-Marie. Smerten fra sykdommen og kjærlighetssorgen formidles i en lavmælt, intens og vond fortelling, der bruddstykker fra nåtid og fortid flettes sammen.

Mia jobber med å utvikle seg som forfatter, og parallelt med sykdomsberetningen følger vi hennes streben etter å uttrykke seg litterært: «Tenk om stoffet bare lå der, tok seg til rette i min høyre hjernehalvdel, kanskje jeg hadde en hel bokserie i arkivet mitt. Tenk om jeg ikke rakk å skrive den.» Kreften blir en trussel mot historiene som kanskje ikke vil bli fortalt. Språkføringen i boken er kreativ, overaskende og billedlig, som da Mia deler sine tanker etter at hun har fătt kreftdiagnosen: «Men jeg vil ikke se de store sammenhengene, at livet blir til mot døden, at når trærne mister bladene, blir utsikten fra kjøkkenvinduet bedre. Jeg vil hjem, snu den nye stolen bort fra vinduet og skrive om noe annet.»

Forfatteren, som selv har hatt kreft, har etter mitt skjønn lyktes i å skrive en original og smertefull roman om sykdom og kjærlighet. Historien viser at et liv er så mye mer enn sykdommen og diagnosen. Anbefales.

Tone Skaali

Voksenpsykiatrisk avdeling Vinderen

Diakonhjemmet sykehus

\section{Syke barn er mer enn sin diagnose}

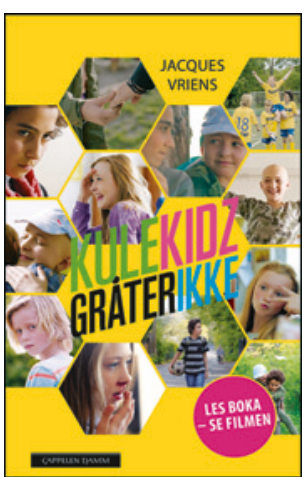

Jacques Vriens

Kule kidz gråter ikke

251 s. Oslo: Cappelen Damm, 2014

Pris NOK 149

ISBN 978-82-02-43769-5

Denne lettleste boken henvender seg til barn i alderen fra 9 til 12 år og handler om 12 år gamle Akkie som utvikler leukemi. Akkie er ei tøff og varmhjertet jente, som har et nært forhold til sin kloke lærer. Vi følger henne, og ikke minst klassekameratene, gjennom sykdomsperioden og det endelige farvel. Boken tar opp mange av livets alvorlige spørsmål på en ærlig og aldersadekvat måte, hovedsakelig sett fra klassekameratenes synsvinkel.

Forfatteren av denne boken er en tidligere lærer uten medisinsk bakgrunn, så dersom det er medisinsk informasjon om barnekreft som er motivet for å lese boken, blir man skuffet. Boken fokuserer på det friske hos den kreftsyke. Betydningen av å ha et liv utenfor sykehuset samtidig med kreftbehandlingen. Den behandler også temaet barns død på en skånsom, medfølende og klok måte, som gir rom for ettertanke. Jeg leste boken sammen med min 11 år gamle datter. Hun likte den godt og gjorde seg mange nyttige refleksjoner underveis.

Personlig kunne jeg tenke meg mer medisinsk realistiske rammer rundt historien, samtidig som jeg liker at boken fokuserer på at syke barn er mye mer enn sin diagnose. Både leger, foreldre og lærere har godt av å bli minnet på de alvorlig syke barnas store behov for og glede av å være sammen med venner og fortsatt være en aktiv deltaker i sitt vanlige miljø.

Språket i boken halter til tider, men jeg tror mange barn vil ha glede av å lese den. Samtidig vet jeg at kreftsyke barn og unge ved min egen avdeling vegrer seg mot å lese boken fordi den ender med en utilslørt fortelling om døden.

\section{Ellen Ruud}

Barneonkolog, Barnemedisinsk seksjon for blod og kreftsykdommer Oslo universitetssykehus 